\title{
Effect of Alkalinity on Catalytic Activity of Iron-Manganese Co-Oxide in Removing Ammonium and Manganese: Performance and Mechanism
}

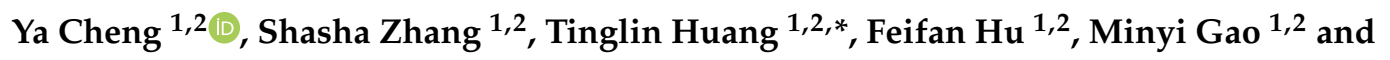 \\ Xiruo Niu ${ }^{1,2}$ \\ 1 Key Laboratory of Northwest Resource, Environment and Ecology, MOE, Xi'an University of Architecture \\ and Technology, Xi'an 710055, China; chengya.xauat@outlook.com (Y.C.); silenceee26@163.com (S.Z.); \\ hufeifanhhh@163.com (F.H.); 18628613581@163.com (M.G.); niuxiruoajiu@163.com (X.N.) \\ 2 Shaanxi Key Laboratory of Environmental Engineering, Xi'an University of Architecture and Technology, \\ Xi'an 710055, China \\ * Correspondence: huangtinglin@xauat.edu.cn; Tel.: +86-029-8220-1038; Fax: +86-029-8220-2729
}

Received: 21 December 2019; Accepted: 24 January 2020; Published: 27 January 2020

check for updates

\begin{abstract}
In this study, a pilot-scale experimental filter system was used to investigate the effect of bicarbonate alkalinity on the activity of an $\mathrm{Fe}-\mathrm{Mn}$ co-oxide for ammonium and manganese removal from surface water. The results showed that an increase in alkalinity to $150 \mathrm{mg} / \mathrm{L}$ (calculated as $\mathrm{CaCO}_{3}$ ) by the addition of $\mathrm{NaHCO}_{3}$ significantly promoted the activity of the $\mathrm{Fe}-\mathrm{Mn}$ co-oxide. The ammonium and manganese removal efficiencies of the Fe-Mn co-oxide increased from $40 \%$ to $95 \%$ and $85 \%$ to $100 \%$, respectively. After $\mathrm{NaHCO}_{3}$ was no longer added, the activity of the filter column remained. Moreover, $\mathrm{pH}(7.4-8.0)$ and temperature $\left(12.0-16.0^{\circ} \mathrm{C}\right)$ were not the main factors affecting the activity of the filter, and had no significant effect on the activity of the filter. Further characterization analysis of the Fe-Mn co-oxide filter film showed that after alkalinity was increased, the accumulation of aluminum on the filter media surface decreased from $3.55 \%$ to $0.16 \%$ and the oxide functional groups changed. This was due to the action of bicarbonate and the residual aluminum salt coagulant in the filter, which caused the loss of $\mathrm{Al}$ from the surface of the filter media and weakened the influence of the aluminum salt coagulant on the activity of the Fe-Mn co-oxide; hence, the activity was recovered.
\end{abstract}

Keywords: Fe-Mn co-oxide; filter media; surface water; alkalinity; activity recovery

\section{Introduction}

In recent years, ammonium $\left(\mathrm{NH}_{4}{ }^{+}\right)$and manganese $\left(\mathrm{Mn}^{2+}\right)$ have been common pollutants in surface waters, which have deleterious impacts on drinking water treatment plants as well as posing a severe threat to people's health [1-4]. Excessive $\mathrm{NH}_{4}{ }^{+}$in drinking water is undesirable and may cause numerous problems: (1) $\mathrm{NH}_{4}{ }^{+}$contamination can create issues of taste and odor in water as well as eutrophication of surface waters [5-7]; (2) $\mathrm{NH}_{4}{ }^{+}$not only decreases the efficiency of chlorine disinfection but also leads to the generation of toxic disinfection byproducts [5]; (3) excessive intake of $\mathrm{NH}_{4}{ }^{+}$may be oxidized to nitrates $\left(\mathrm{NO}_{3}{ }^{-}\right)$and nitrites $\left(\mathrm{NO}_{2}{ }^{-}\right)$, which can produce carcinogenic nitrosamines [8-10]. Manganese is present as $\mathrm{Mn}^{2+}$, the oxidation of which results in the formation of a dark brown $\mathrm{MnO}_{2}$ precipitate that can result in the discoloration of water or cause pipe blockages [11,12]. Mn in drinking water has also been linked to neurotoxic effects in children $[13,14]$ and might affect the health of consumers [15-17]. At present, the general methods to remove $\mathrm{NH}_{4}{ }^{+}$during drinking water treatment are adsorption [18], chemical oxidation [19-21], biofiltration processes [22], and membrane separation technology [23]. Meanwhile, many treatment options have been explored for $\mathrm{Mn}^{2+}$ removal, which 
include chemical oxidation [1] and biological processes [24-26]. However, the existing technologies have faced continued problems, including the high cost of oxidants and the poor applicability of microorganisms; hence, it is necessary to develop an affordable process for the efficient removal of $\mathrm{NH}_{4}{ }^{+}$and $\mathrm{Mn}^{2+}$ in surface water.

Our research group recently reported on an iron-manganese (Fe-Mn) co-oxide filter media for $\mathrm{NH}_{4}{ }^{+}$and $\mathrm{Mn}^{2+}$ removal from groundwater $[27,28]$. Given the lack of groundwater resources in China and the fact that most drinking water treatment plants still use surface water, it was used for surface water treatment. However, the aluminum $(\mathrm{Al})$ deriving from the polymeric aluminum ferric chloride coagulant was found to negatively affect the $\mathrm{NH}_{4}{ }^{+}$catalytic activity [29]. Specifically, the activity of the $\mathrm{Fe}-\mathrm{Mn}$ co-oxide filter media decreased gradually when used for surface water treatment, which was termed "inactivated filter media". Hence, the aim of this study is to recover the removal activity of the inactivated $\mathrm{Fe}-\mathrm{Mn}$ co-oxide filter media used for surface water treatment. By comparison, the bicarbonate $\left(\mathrm{HCO}_{3}{ }^{-}\right)$alkalinity was found to be the parameter that differed the most between the groundwater and surface water. In the present study, we systematically investigate the $\mathrm{NH}_{4}{ }^{+}$and $\mathrm{Mn}^{2+}$ removal efficiencies and the effects of $\mathrm{HCO}_{3}{ }^{-}$alkalinity on the chemical catalytic oxidation of the Fe-Mn co-oxide filter. Water quality parameters and filter media characterization are analyzed to investigate how the catalytic activity is restored by alkalinity.

\section{Materials and Methods}

\subsection{Experimental Setup}

A pilot-scale filter system was built at a drinking water plant located in $\mathrm{Xi}^{\prime}$ an City, China. The pilot system consisted of a transparent plexiglass column with an inner diameter of $10 \mathrm{~cm}$ and a height of $270 \mathrm{~cm}$, within which the Fe-Mn co-oxide filter media were packed to a height of $90 \mathrm{~cm}$. The bottom of the filter column was supported by a $15 \mathrm{~cm}$ high layer of cobblestone, and a water level of $30-40 \mathrm{~cm}$ was maintained in the upper part of the filter layer during operation. Five sampling points were distributed along the depth of the filter column, located at $0,10,30,50$, and $90 \mathrm{~cm}$ (from top to bottom), as illustrated in Figure 1. The characteristics of the Fe-Mn co-oxide filter media that filled the filter and the backwashing parameters of the filter were consistent with our previous research [30-32].

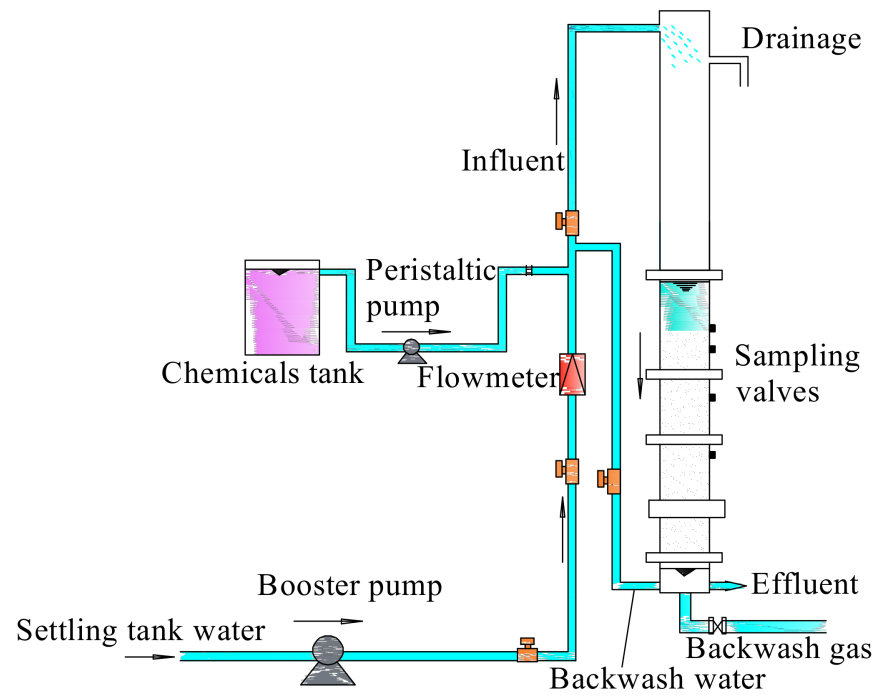

Figure 1. Schematic diagram of the pilot-scale experiment system.

Raw, untreated surface water was the influent of the surface water treatment plant. The feed water of the filter system was the effluent from a sedimentation tank in the pilot-scale treatment system. 
The parameters of the feed water are listed in Table 1. The filter was operated at a filtration rate of $6-7 \mathrm{~m} / \mathrm{h}$ in downflow.

Table 1. Water quality parameters of the feed water.

\begin{tabular}{ccc}
\hline Parameter & Unit & Range \\
\hline $\mathrm{pH}$ & & $7.0-8.0$ \\
Temperature & ${ }^{\circ} \mathrm{C}$ & $10-20$ \\
$\mathrm{Mg}^{2+}$ & $\mathrm{mg} / \mathrm{L}$ & $3-4$ \\
$\mathrm{Ca}^{2+}$ & $\mathrm{mg} / \mathrm{L}$ & $25-28$ \\
$\mathrm{SO}_{4}{ }^{2-}$ & $\mathrm{mg} / \mathrm{L}$ & $16-25$ \\
$\mathrm{Cl}^{-}$ & $\mathrm{mg} / \mathrm{L}$ & $10-20$ \\
Turbidity & $\mathrm{NTU}$ & $0.1-2.0$ \\
Dissolved oxygen & $\mathrm{mg} / \mathrm{L}$ & $6-7$ \\
$\mathrm{NH}_{4}{ }^{+}-\mathrm{N}^{1}$ & $\mathrm{mg} / \mathrm{L}$ & $1-2$ \\
$\mathrm{Mn}^{2+}$ & $\mathrm{mg} / \mathrm{L}$ & $1-2$ \\
\hline
\end{tabular}

${ }^{1} \mathrm{NH}_{4}{ }^{+}-\mathrm{N}$ : the concentration of $\mathrm{NH}_{4}{ }^{+}$calculated as nitrogen element.

\subsection{Experimental Methods}

Given the relatively low $\mathrm{NH}_{4}{ }^{+}$and $\mathrm{Mn}^{2+}$ concentrations in the surface water, the metering pump was adapted to dose a certain concentration of $\mathrm{NH}_{4} \mathrm{Cl}$ and $\mathrm{MnCl}_{2}$ solution into the influent of the filter column to adjust the $\mathrm{Mn}^{2+}$ and $\mathrm{NH}_{4}{ }^{+}$concentrations (see below). In this study, the operation of the pilot-scale filter column was divided into four phases: before adding $\mathrm{NaHCO}_{3}$ (phase I: days 0-8), maintaining $100 \mathrm{mg} / \mathrm{L}$ alkalinity (phase II: days 9-19), maintaining $150 \mathrm{mg} / \mathrm{L}$ alkalinity (phase III: days 20-38), and alkalinity no longer added (phase IV: days 39-50). Sodium bicarbonate $\left(\mathrm{NaHCO}_{3}\right)$ was used to adjust the alkalinity (calculated as $\mathrm{CaCO}_{3}$ ) in the filter. At each phase, the influent $\mathrm{NH}_{4}{ }^{+}$and $\mathrm{Mn}^{2+}$ concentrations were maintained at 1-2 mg/L, and the $\mathrm{NH}_{4}{ }^{+}$and $\mathrm{Mn}^{2+}$ removal efficiencies of the filter media at different phases were measured. Specifically, the ammonium and manganese removal efficiency of the filter was calculated according to Equation (1) [33]:

$$
\text { removal efficiency }(\%)=\frac{c_{\text {influent }}-c_{\text {effluent }}}{c_{\text {influent }}} \times 100 \%
$$

where $\mathrm{c}$ is the concentration $(\mathrm{mg} / \mathrm{L})$.

\subsection{Analytical Methods}

During the pilot-scale system experiment, the effluent samples taken from different heights of the filter column were filtered through a $0.45 \mu \mathrm{m}$ membrane filter. The $\mathrm{pH}$, temperature, alkalinity, and $\mathrm{NH}_{4}{ }^{+}$and $\mathrm{Mn}^{2+}$ concentrations of the effluent were measured daily. The $\mathrm{pH}$ was determined using a PHS-3C $\mathrm{pH}$ meter. $\mathrm{NH}_{4}{ }^{+}, \mathrm{Mn}^{2+}$, and alkalinity were measured according to the guidelines set by the Ministry of Environmental Protection of China [34]. Specifically, the concentrations of $\mathrm{NH}_{4}{ }^{+}$ and $\mathrm{Mn}^{2+}$ were measured by Nessler's reagent spectrophotometry and potassium periodate oxidative spectrophotometry, respectively.

To explore the variations in morphology, structure, and composition of the Fe-Mn co-oxide filter film during the different operation phases, the following methods were used to periodically analyze the characteristics of the oxide film. The microtopography of the Fe-Mn co-oxide was measured using scanning electron microscopy (SEM) equipment (FEI Quanta 600F). The elemental composition of the samples was determined by energy dispersive X-ray spectroscopy (EDS) equipment (Oxford INCA/ENERGY-350). The specific surface area and pore size of the filter material was measured by Brunauer-Emmett-Telle (BET) equipment (Quantachrome Autosorb iQ2). The microstructure of the samples was analyzed using Fourier transform spectroscopy (FTIR) (chemical bond) equipment (Nicolet iS50) and X-ray diffraction (XRD) (crystal structure and crystallinity) equipment (Ultiman IV). 


\section{Results and Discussion}

\subsection{Effect of Alkalinity on $\mathrm{NH}_{4}{ }^{+}$Removal Performance of the Filter System}

The pilot-scale filter system was operated continuously for 50 days. The $\mathrm{NH}_{4}{ }^{+}$concentration in the influent and effluent at different phases is shown in Figure 2. During phase I, the influent alkalinity was the original alkalinity of the surface water $(50-65 \mathrm{mg} / \mathrm{L})$, and the $\mathrm{NH}_{4}{ }^{+}$removal performance of the filter was always poor. In particular, when the influent $\mathrm{NH}_{4}{ }^{+}$concentration was $1 \mathrm{mg} / \mathrm{L}$, the effluent $\mathrm{NH}_{4}{ }^{+}$concentration was $\sim 0.6 \mathrm{mg} / \mathrm{L}$ and the removal efficiency was only $40 \%$. After the influent alkalinity was increased to $100 \mathrm{mg} / \mathrm{L}$ (phase II), although the $\mathrm{NH}_{4}{ }^{+}$removal efficiency increased, it did not change significantly. During phase III, the influent alkalinity was $150 \mathrm{mg} / \mathrm{L}$ and the influent $\mathrm{NH}_{4}{ }^{+}$concentration was increased from 1 to $1.5 \mathrm{mg} / \mathrm{L}$; the results showed that the effluent $\mathrm{NH}_{4}{ }^{+}$ concentration decreased gradually over time during phase III (Figure 2). From the 30th day, the effluent $\mathrm{NH}_{4}{ }^{+}$concentration was $<0.1 \mathrm{mg} / \mathrm{L}$, and the $\mathrm{NH}_{4}{ }^{+}$removal efficiency subsequently improved to be consistently $>95 \%$. The results showed that the increase in alkalinity was beneficial to the removal of $\mathrm{NH}_{4}{ }^{+}$by the filter. To further explore whether the $\mathrm{NH}_{4}{ }^{+}$removal activity of the filter was maintained, alkalinity was not added during phase IV. The filter system continued to exhibit an excellent $\mathrm{NH}_{4}^{+}$ removal performance; even if the influent $\mathrm{NH}_{4}{ }^{+}$concentration was as high as $1.5 \mathrm{mg} / \mathrm{L}$, no NH$_{4}{ }^{+}$was detected in the effluent and the removal efficiency was always $>95 \%$ (Figure 2). The experimental results demonstrated that the $\mathrm{NH}_{4}{ }^{+}$removal ability of the filter was indeed improved compared with that before increasing alkalinity.

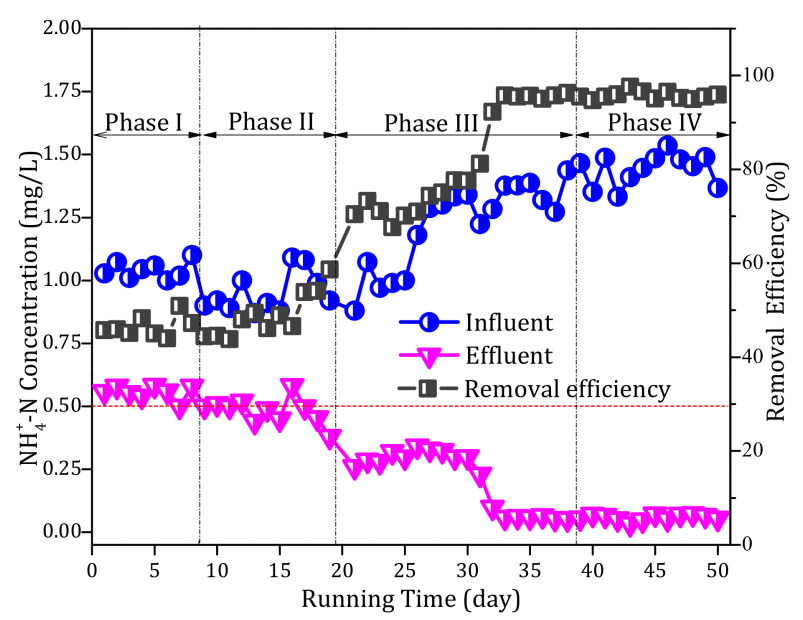

Figure 2. Profiles of the ammonium $\left(\mathrm{NH}_{4}{ }^{+}\right)$removal performance over the continuous operational period of the pilot filter system.

Figure 3 presents the $\mathrm{NH}_{4}{ }^{+}$removal efficiency with filter column depth during different operational phases and the corresponding kinetics of $\mathrm{NH}_{4}{ }^{+}$oxidation. Figure 3 a shows that as the influent alkalinity increased with each phase, the $\mathrm{NH}_{4}{ }^{+}$removal efficiency at given depths improved significantly. At $30 \mathrm{~cm}$ depth, the removal efficiency was only $15 \%$ during phase I, but increased to $25 \%$ during phase II and then $47 \%$ during phase III, which was maintained during phase IV.

$\mathrm{NH}_{4}{ }^{+}$was oxidized to nitrite and nitrate during its removal by the filter column (Equation (2)) [28]. The $\mathrm{NH}_{4}{ }^{+}$removal kinetic was assumed to follow the pseudofirst order kinetic model expressed by Equation (3) [27]:

$$
\begin{gathered}
\mathrm{NH}_{4}^{+}+2 \mathrm{O}_{2} \rightarrow 2 \mathrm{H}^{+}+\mathrm{H}_{2} \mathrm{O}+\mathrm{NO}_{3}^{-} \\
-\frac{d\left[\mathrm{NH}_{4}^{+}\right]}{d t}=k\left[\mathrm{NH}_{4}^{+}\right]
\end{gathered}
$$

where $\mathrm{k}$ is the rate constant $\left(\mathrm{min}^{-1}\right)$. 
As shown in Figure 3b, the relationship between $\log \left\{\left[\mathrm{NH}_{4}{ }^{+}\right]_{\mathrm{t}} /\left[\mathrm{NH}_{4}{ }^{+}\right]_{\mathrm{o}}\right\}$ and the empty bed contact time ( $\mathrm{min}$ ) was linear. During phase $\mathrm{I}$, the value of $\mathrm{k}_{8}$ (the rate constant on day 8 ) in the filter column was $0.030 \mathrm{~min}^{-1}$. As alkalinity was increased, the $\mathrm{k}$ value increased significantly to $0.146 \mathrm{~min}^{-1}$ on day 37 (phase III) and then further to $0.151 \mathrm{~min}^{-1}$ on day 48 after ceasing to add alkalinity (phase IV). This implies that the addition of alkalinity was beneficial for continuous $\mathrm{NH}_{4}{ }^{+}$removal by the filter column.

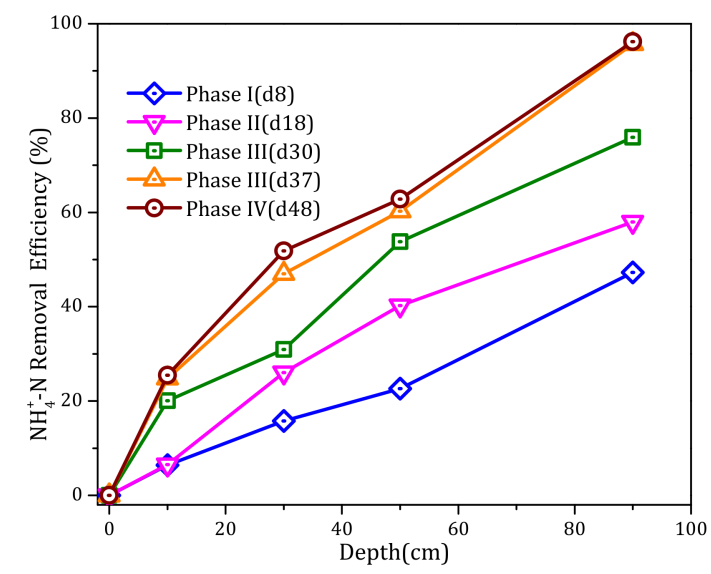

(a)

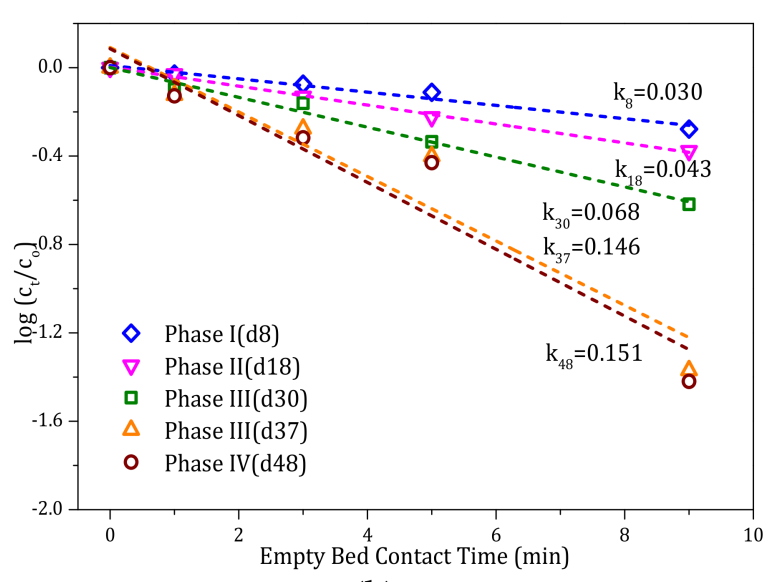

(b)

Figure 3. (a) Ammonium $\left(\mathrm{NH}_{4}{ }^{+}\right)$removal efficiency with filter column depth during different phases, and (b) linear regression analysis of $\mathrm{NH}_{4}{ }^{+}$depletion with the empty bed contact time during different phases. Day (d) and rate constant (k).

\subsection{Effect of Alkalinity on $\mathrm{Mn}^{2+}$ Removal Performance of the Filter System}

During the continuous operation of the pilot-scale filter system, the $\mathrm{Mn}^{2+}$ concentration in the influent and effluent were measured, as shown in Figure 4. During phase I, the influent alkalinity was 50-65 mg/L and the $\mathrm{Mn}^{2+}$ removal performance was always good. Specifically, when the influent $\mathrm{Mn}^{2+}$ concentration was $1 \mathrm{mg} / \mathrm{L}$, the effluent $\mathrm{Mn}^{2+}$ concentration remained more or less constant and was always close to the limit of China's drinking water quality standards $(0.1 \mathrm{mg} / \mathrm{L})$. The removal efficiency during phase I was $\sim 85 \%$ (Figure 4 ), which improved considerably during phase II (after 10 days of operation) and reached up to $100 \%$ after the influent alkalinity was increased to $100 \mathrm{mg} / \mathrm{L}$. When the influent $\mathrm{Mn}^{2+}$ concentration was increased from 1 to $1.5 \mathrm{mg} / \mathrm{L}$ during phase II, despite a small increase on day 18 , the $\mathrm{Mn}^{2+}$ concentration in the effluent subsequently reduced to near zero. During phase III, when the influent alkalinity was increased to $150 \mathrm{mg} / \mathrm{L}$, the $\mathrm{Mn}^{2+}$ concentration in the effluent remained near zero and the removal efficiency was consistently 100\%. In addition, during phase IV, when no further alkalinity was added, the filter still showed an excellent $\mathrm{Mn}^{2+}$ removal performance, and the $\mathrm{Mn}^{2+}$ concentration in the effluent remained near zero (Figure 4). Hence, although the effect of alkalinity on the $\mathrm{Mn}^{2+}$ removal rate was not obvious, the $\mathrm{Mn}^{2+}$ removal capacity of the filter media increased from 1 to $\geq 1.5 \mathrm{mg} / \mathrm{L}$. 


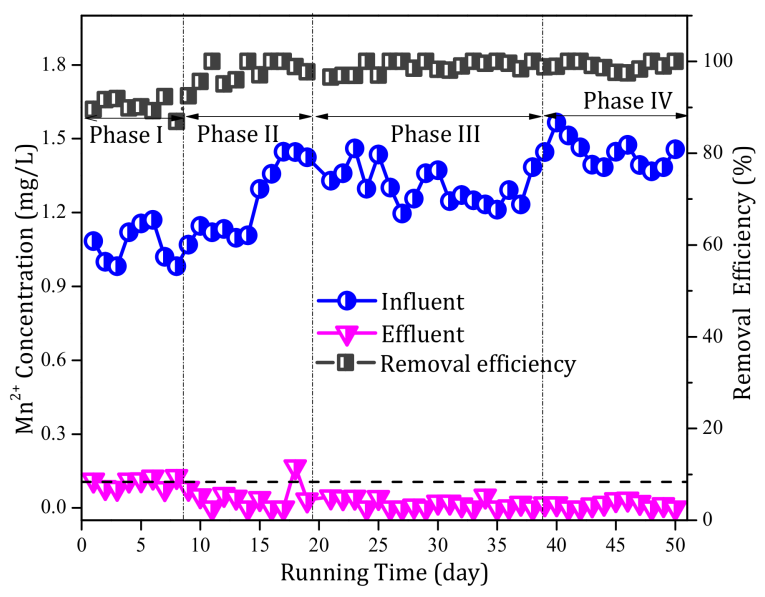

Figure 4. Profiles of the manganese $\left(\mathrm{Mn}^{2+}\right)$ removal performance over the continuous operational period of the pilot filter system.

Figure 5 illustrates the $\mathrm{Mn}^{2+}$ removal efficiency over the depth of the filter column during different phases and the kinetics of $\mathrm{Mn}^{2+}$ oxidation. From phase I to phase II, as the influent alkalinity was increased, the $\mathrm{Mn}^{2+}$ removal efficiency increased considerably at given depths. In particular, the removal efficiency increased from $30 \%$ to $55 \%$ at the depth of $10 \mathrm{~cm}$. After phase II, the $\mathrm{Mn}^{2+}$ removal efficiency tended to be stable, and the filter media maintained an excellent $\mathrm{Mn}^{2+}$ removal performance when alkalinity was no longer added in phase IV.

During the removal of $\mathrm{Mn}^{2+}$ from the filter column, the dissolved $\mathrm{Mn}^{2+}$ was converted into an insoluble manganese oxide and removed according to Equation (4) [32]. When the dissolved oxygen and $\mathrm{pH}$ remained invariable, $\mathrm{Mn}^{2+}$ depletion followed the first-order linear rate (Equation (5)) $[35,36]$ :

$$
\begin{aligned}
& 2 \mathrm{Mn}(\mathrm{II})+\mathrm{O}_{2}+2 \mathrm{H}_{2} \mathrm{O} \rightarrow 2 \mathrm{Mn}(\mathrm{IV}) \mathrm{O}_{2}+4 \mathrm{H}^{+} \\
&-\frac{d\left[\mathrm{Mn}^{2+}\right]}{d t}=k\left[\mathrm{Mn}^{2+}\right]
\end{aligned}
$$

where $\mathrm{k}$ is the rate constant $\left(\mathrm{min}^{-1}\right)$.

As shown in Figure $5 b$, the relationship between $\log \left\{\left[\mathrm{Mn}^{2+}\right]_{t} /\left[\mathrm{Mn}^{2+}\right]_{o}\right\}$ and the empty bed contact time ( $\mathrm{min}$ ) was linear. During phase I, the value of $\mathrm{k}_{8}$ in the filter was $0.122 \mathrm{~min}^{-1}$. With increased alkalinity, the $\mathrm{k}$ value increased gradually to $0.215 \mathrm{~min}^{-1}$ on day 37 (phase III) and increased further to $0.239 \mathrm{~min}^{-1}$ on day 48 after ceasing to add alkalinity (phase IV). This indicated that the $\mathrm{Mn}^{2+}$ removal performance of the filter column was maintained. The results therefore demonstrated that the increase in alkalinity had a positive effect on the $\mathrm{Mn}^{2+}$ removal activity. 


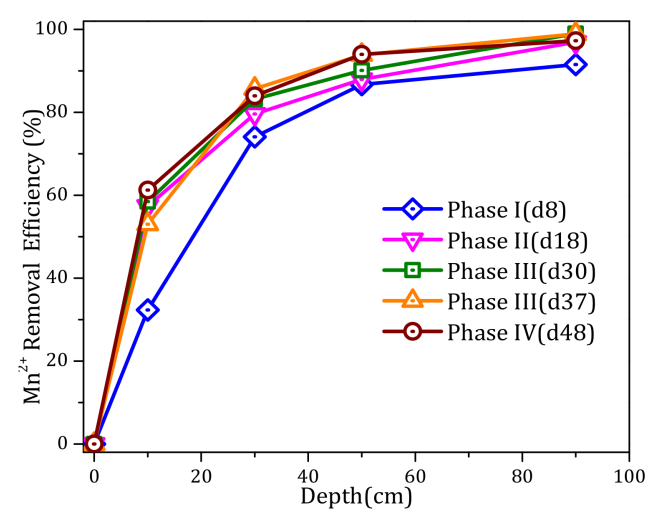

(a)

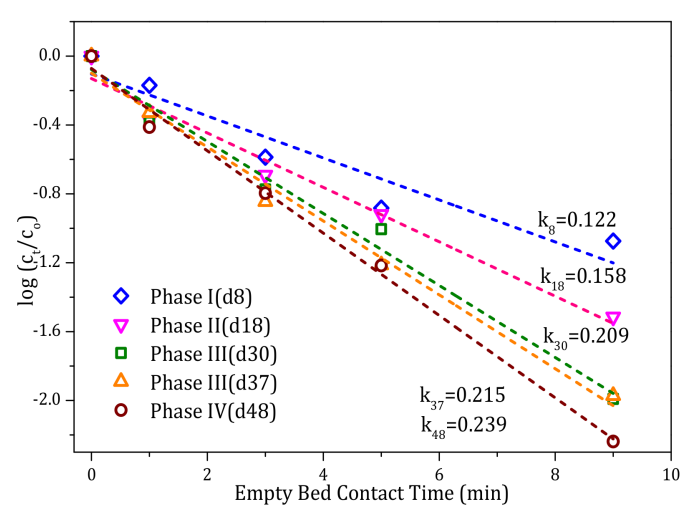

(b)

Figure 5. (a) Manganese $\left(\mathrm{Mn}^{2+}\right)$ removal efficiency with filter column depth during different phases, and (b) linear regression analysis of $\mathrm{Mn}^{2+}$ depletion with the empty bed contact time during different phases. Day (d) and rate constant (k).

\subsection{Variation of Other Water Quality Parameters}

The experimental results presented in Sections 3.1 and 3.2 showed that the increase in alkalinity had a favorable influence on the $\mathrm{NH}_{4}{ }^{+}$and $\mathrm{Mn}^{2+}$ removal capabilities of the Fe-Mn co-oxide. A previous study found that the activity of Fe-Mn co-oxide was inhibited to a certain extent at low temperatures [37]. Meanwhile, the removal activity of Fe-Mn co-oxide was shown in another study to be affected by $\mathrm{pH}$ [38]. To further investigate the reasons for the difference in the activity of the filter during different stages, the influent temperature and $\mathrm{pH}$ of the filter were compared.

\subsubsection{Temperature}

Figure 6 exhibits the variations in the influent temperature of the filter over the entire operational period. The influent temperature tended to rise over the period of operation. During phase II, the gradual improvement in the $\mathrm{NH}_{4}{ }^{+}$and $\mathrm{Mn}^{2+}$ removal performances should have been independent of temperature as a result of the fluctuating temperature $\left(12-14{ }^{\circ} \mathrm{C}\right)$ during this stage. Similarly, between days 23 and 27 of phase III, the temperature decreased obviously and the $\mathrm{NH}_{4}{ }^{+}$removal performance continued to improve. During phase IV, when the temperature dropped significantly, the $\mathrm{NH}_{4}{ }^{+}$and $\mathrm{Mn}^{2+}$ removal capacities remained stable. The results therefore demonstrated that temperature was not the main reason for the enhancement of the removal capability of the filter system over the entire operation period.

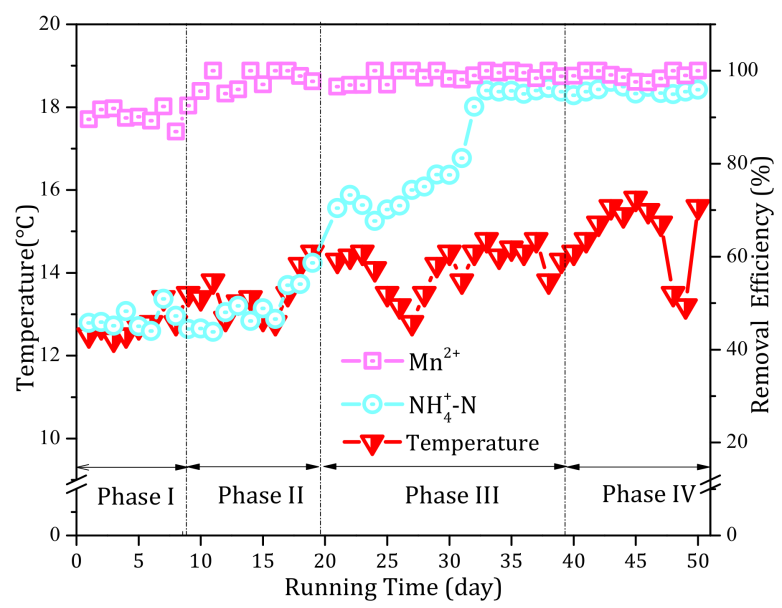

Figure 6. Profiles of the influent temperature during the continuous operational period of the pilot filter system. 


\subsubsection{1. $\mathrm{pH}$}

Figure 7 presents the influent $\mathrm{pH}$ values of the filter over the entire operation period. During phase I, the influent $\mathrm{pH}$ of the filter was $\sim 7.5$. When the alkalinity was increased to $100 \mathrm{mg} / \mathrm{L}$ (phase II) and $150 \mathrm{mg} / \mathrm{L}$ (phase III), the $\mathrm{pH}$ gradually increased to 7.7 and 7.85, respectively. Hence, with increasing alkalinity, the influent $\mathrm{pH}$ also increased. This was consistent with the improved $\mathrm{NH}_{4}{ }^{+}$and $\mathrm{Mn}^{2+}$ removal efficiencies; hence, it is possible that the increased $\mathrm{NH}_{4}{ }^{+}$and $\mathrm{Mn}^{2+}$ removal efficiencies might have arisen from $\mathrm{pH}$. However, the $\mathrm{pH}$ decreased to 7.5 after ceasing to add alkalinity (phase IV), and yet the $\mathrm{NH}_{4}{ }^{+}$and $\mathrm{Mn}^{2+}$ removal performance remained superior. Therefore, $\mathrm{pH}$ was not the main cause for the improved $\mathrm{NH}_{4}{ }^{+}$and $\mathrm{Mn}^{2+}$ removal performances of the filter system.

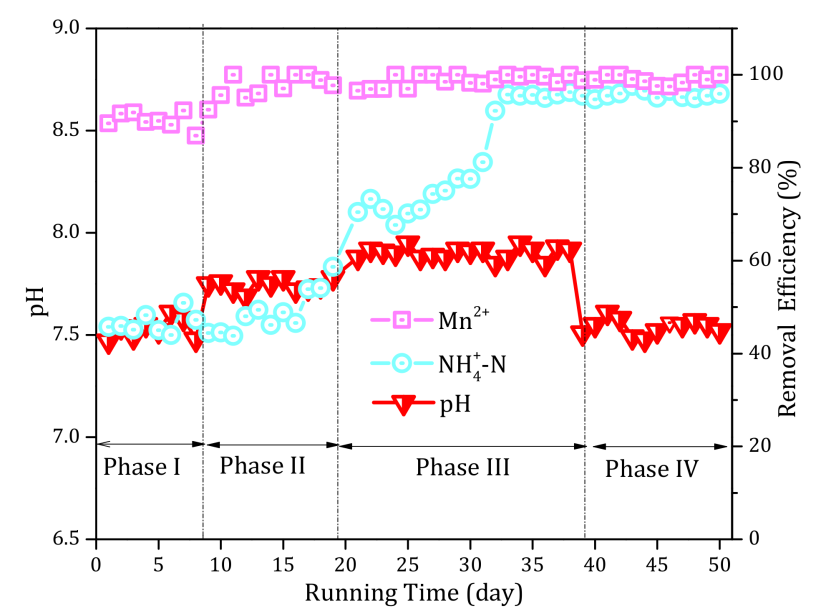

Figure 7. Profiles of the influent $\mathrm{pH}$ during the continuous operational period of the pilot filter system.

\subsection{Characterization of $\mathrm{Fe}-\mathrm{Mn}$ Co-oxide Film}

\subsubsection{Morphology Analysis}

The build-up and surface microtopography of the Fe-Mn co-oxide at different phases during the entire operational period were analyzed by SEM, as shown in Figure 8. The images obtained from the Fe-Mn co-oxide sample showed that the media consisted of many small aggregated particles (Figure 8a,d,g), which led to a rough surface and a porous structure. Adsorption onto the oxide film should be the first step for the removal of $\mathrm{NH}_{4}{ }^{+}$and $\mathrm{Mn}^{2+}$ by the $\mathrm{Fe}-\mathrm{Mn}$ co-oxide, such that the relatively loose structure could facilitate the transfer and degradation of $\mathrm{NH}_{4}{ }^{+}$and $\mathrm{Mn}^{2+}$. Moreover, it can be seen that the surface of the filter media exhibited relatively rough folds (Figure 8b,e,h), which were formed by the Fe-Mn co-oxide during the removal of pollutants adhered to the surface of the filter media. During phase I, the surface was reticular (Figure 8b,c) and could facilitate the contact and adsorption of pollutants; furthermore, $\mathrm{NH}_{4}{ }^{+}$and $\mathrm{Mn}^{2+}$ were removed by the catalytic oxidation of the filter media. However, on the basis of the reticular structure, the surface of the filter media during phase III showed more folds (Figure 8e,f) that provided more adsorption sites, which was consistent with the increased removal activity with increased alkalinity during this stage. In addition, there was no significant difference in morphology between phases III and IV (Figure 8f,i), which was consistent with the well-maintained activity of the filter after ceasing to add alkalinity. 


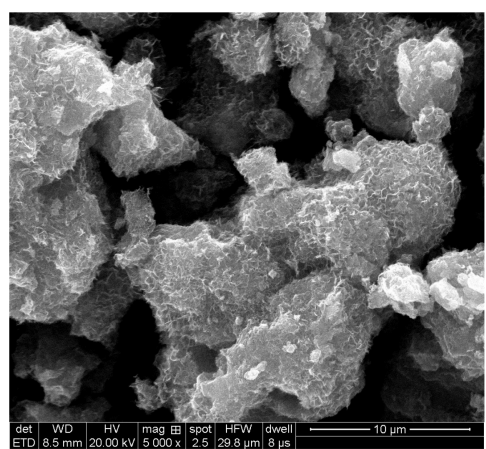

(a)

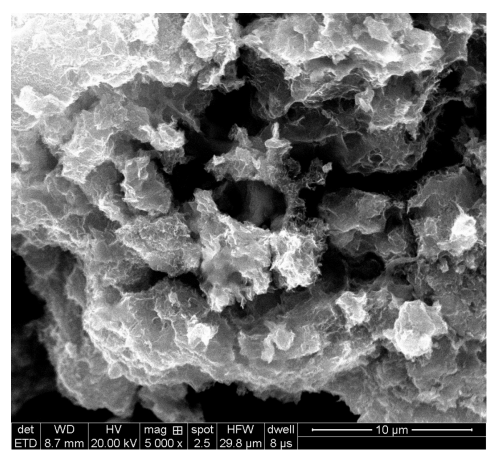

(d)

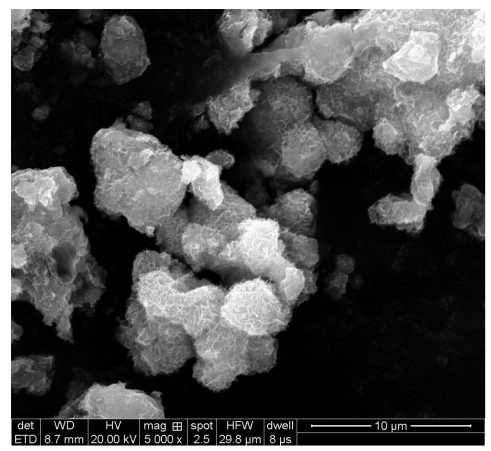

(g)

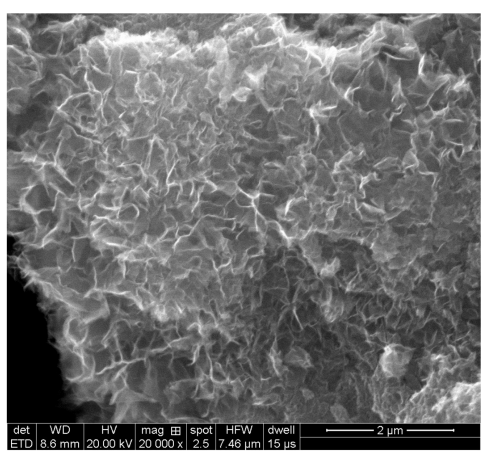

(b)

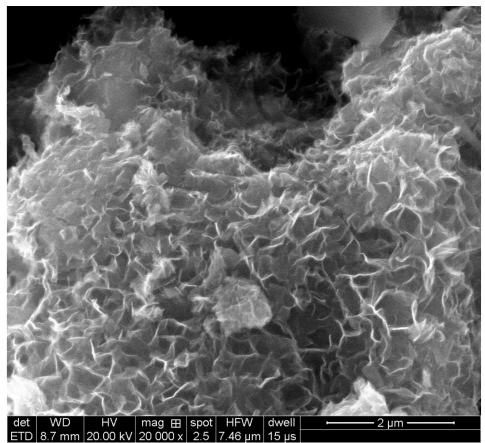

(e)

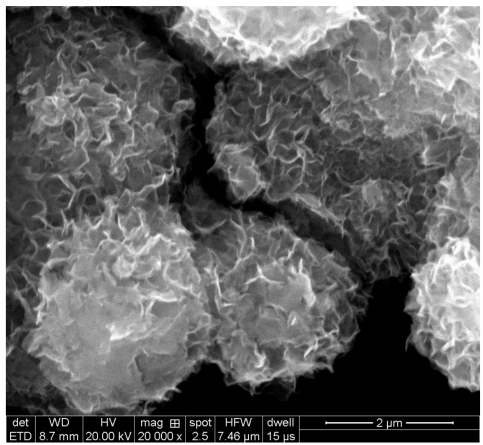

(h)

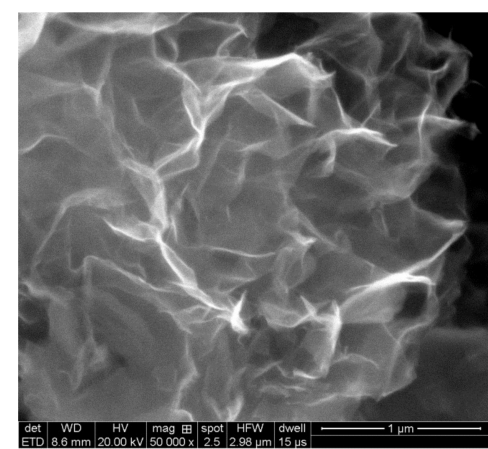

(c)

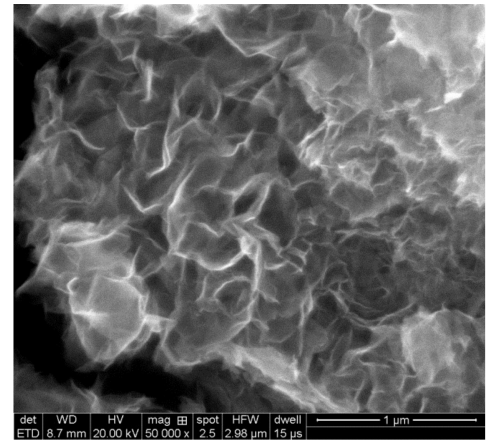

(f)

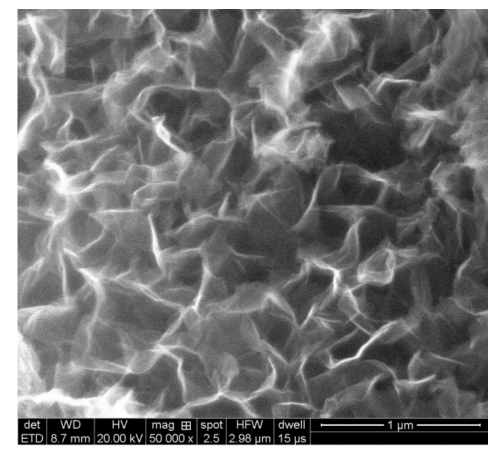

(i)

Figure 8. Scanning electron microscope (SEM) images of Fe-Mn co-oxide filter media during (a, $\mathbf{b}$, and c) phase I; (d, e, and f) phase III; (g, h, and i) phase IV.

In addition, BET was adopted to analyze the surface area $\left(\mathrm{S}_{\mathrm{BET}}\right)$, pore volume $(\mathrm{V})$, and pore size (d) of the samples, and the results are listed in Table 2. The surface areas of the samples collected from phase I, phase III, and phase IV were $8.04,16.46$, and $18.26 \mathrm{~m}^{2} / \mathrm{g}$, respectively. The larger contact surface area implied that there are more adsorption sites on the surface, and the increase in pore volume indicated an increase in reaction channels used to remove contaminants. The pore volume of the filter media collected from phase III and phase IV was larger than that of phase I, thus indicating that an increase in alkalinity could increase the reaction channel for removing contaminants. After increasing the alkalinity, the gradually increasing mesoporous structure was conducive to adsorbing $\mathrm{NH}_{4}{ }^{+}$and $\mathrm{Mn}^{2+}$ to the surface of the Fe-Mn co-oxide filter film for effective removal. Furthermore, the catalytic activity remained excellent even after ceasing to add $\mathrm{HCO}_{3}{ }^{-}$. 
Table 2. Brunauer-Emmett-Telle (BET) analysis of the filter media samples collected from different phases.

\begin{tabular}{cccc}
\hline & BET Surface Area $\left(\mathbf{m}^{\mathbf{2}} \mathbf{g}\right)$ & Pore Volume $\mathbf{( \mathbf { c m } ^ { 3 } / \mathbf { g } )}$ & Pore Size $(\mathbf{n m})$ \\
\hline phase I & 8.04 & 0.03 & 9.89 \\
phase III & 16.46 & 0.06 & 14.65 \\
phase IV & 18.26 & 0.07 & 14.75 \\
\hline
\end{tabular}

\subsubsection{XRD Analysis}

To identify the crystal structure and crystallinity of the Fe-Mn co-oxide, samples from different phases were characterized by XRD. As demonstrated by Figure 9, the XRD patterns generally showed low peak intensities and broad diffraction peaks, which indicated a low crystallinity and a higher number of adsorption sites in the Fe-Mn co-oxide samples. These results agreed with the previous studies, which had a mixed phase structure (birnessite, buserite PDF\#86-1630) [28,39]. Specifically, at different stages of operation, the crystal form and phase of the filter media did not show any obvious change, which indicated that $\mathrm{NaHCO}_{3}$ had no influence on the structure of the Fe-Mn co-oxide film. It was also found that the crystal structure stability of the Fe-Mn co-oxide was always better.

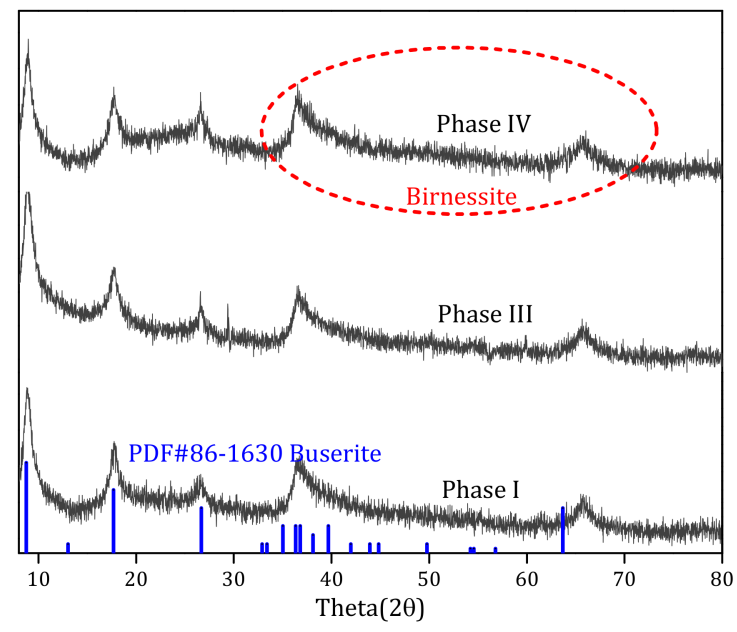

Figure 9. X-ray diffraction (XRD) analysis of the Fe-Mn co-oxide filter media at different operational periods.

\subsubsection{Composition Analysis}

The major elemental composition of the Fe-Mn co-oxide filter media samples collected from the filter was characterized by EDS, the results of which are listed in Table 3. The analysis showed that large amounts of $\mathrm{Mn}$ and $\mathrm{O}$ combined with $\mathrm{Fe}, \mathrm{Ca}, \mathrm{Si}$, and $\mathrm{Al}$ on the surface of the filter media. It is worth noting that $\mathrm{Al}$ is not an original constituent element of the active oxide film. Based on our previous research, after the active oxide film was applied to the surface water treatment, the decreased catalytic oxidation activity may have been caused by the $\mathrm{Al}$ accumulation on the surface of the filter media [30]. Table 3 shows that the $\mathrm{Al}$ accumulation on the filter media surface decreased from $3.55 \%$ before the addition of alkalinity to $0.16 \%$ after $\mathrm{NaHCO}_{3}$ was added. Therefore, it can be inferred that the action of the $\mathrm{HCO}_{3}{ }^{-}$and the residual $\mathrm{Al}$ of the filter media resulted in the loss of $\mathrm{Al}$ from the surface of the filter media and weakened the influence of $\mathrm{Al}$ on the catalytic activity. These results were consistent with those of the $\mathrm{NH}_{4}{ }^{+}$and $\mathrm{Mn}^{2+}$ removal performance (Sections 3.1 and 3.2); the reduced residual $\mathrm{Al}$ resulted in a higher removal efficiency of the filter column. 
Table 3. Surface elemental composition (\%) of the Fe-Mn co-oxide during phases I and IV.

\begin{tabular}{cccccccc}
\hline & $\mathbf{O}$ & $\mathbf{A l}$ & $\mathbf{S i}$ & $\mathbf{K}$ & $\mathbf{C a}$ & $\mathbf{M n}$ & $\mathbf{F e}$ \\
\hline Phase I & 59.85 & 3.55 & 2.74 & 0.35 & 2.65 & 30.19 & 0.68 \\
Phase IV & 60.95 & 0.16 & 2.33 & 0.11 & 3.05 & 32.13 & 1.25 \\
\hline
\end{tabular}

\subsubsection{FTIR Analysis}

FTIR was used to explore the structural difference of the Fe-Mn co-oxide before and after adding $\mathrm{NaHCO}_{3}$, and the results are shown in Figure 10. There was no great difference among the oxide samples, which mainly contained three peaks: 3300,1628 , and $1037 \mathrm{~cm}^{-1}$. The broad peak at $3300 \mathrm{~cm}^{-1}$ was assigned to the stretching vibration of water molecules or -OH groups $[40,41]$, whereas the peak at $1628 \mathrm{~cm}^{-1}$ was related to the bending vibration of structural water molecules or -OH groups [41,42], and the peak at $1037 \mathrm{~cm}^{-1}$ was linked to the bending vibration of the $-\mathrm{OH}$ group (vMn-O-H) [43]. However, it is noteworthy that after the addition of alkalinity, the surface structure of the oxide filter media changed and the intensity of the peak at $1037 \mathrm{~cm}^{-1}$ was obviously enhanced. This indicates that the $\mathrm{Mn}-\mathrm{OH}$ bond in the $\mathrm{Fe}-\mathrm{Mn}$ co-oxide was restored in a high alkalinity environment. Combined with the results of the EDS, the accumulation of Al decreased significantly with the increased catalytic activity of the filter media. Therefore, it was speculated that the $\mathrm{HCO}_{3}{ }^{-}$alkalinity promoted the recovery of $\mathrm{Mn}-\mathrm{OH}$ bonds, and the recovery of catalytic activity was attributed to the combination of $\mathrm{HCO}_{3}{ }^{-}$and $\mathrm{Al}$.

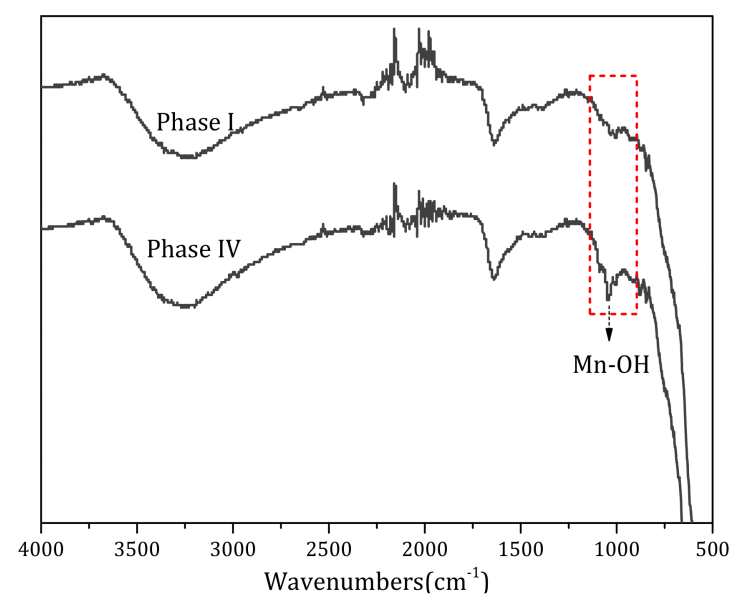

Figure 10. Fourier transform spectroscopy (FTIR) spectra of the Fe-Mn co-oxide during phases I and IV.

\subsection{Mechanism of the Influence of Alkalinity on the Activity}

The results in Sections 3.1-3.4 collectively suggest that the $\mathrm{NH}_{4}{ }^{+}$and $\mathrm{Mn}^{2+}$ removal activities of the inactivated filter media were recovered after operation in high alkalinity conditions, and that temperature and $\mathrm{pH}$ were not the reasons for the recovery of activity. The oxidation process of $\mathrm{NH}_{4}{ }^{+}$ produced $\mathrm{H}^{+}$, which reduced the $\mathrm{pH}$ and inhibited the further progress of the oxidation of $\mathrm{NH}_{4}{ }^{+}$. Therefore, the increased alkalinity buffered a decrease in $\mathrm{pH}$ and promoted the oxidation of $\mathrm{NH}_{4}{ }^{+}$, such that the activity of the filter column was promoted during the addition of alkalinity. The FTIR and EDX analysis illustrated that after a period of time in high alkalinity conditions, the functional groups and $\mathrm{Al}$ content of the filter media changed significantly. This was mainly due to the action of $\mathrm{HCO}_{3}{ }^{-}$ and the remaining $\mathrm{Al}$ salt coagulant in the filter, which caused the residual $\mathrm{Al}$ on the surface to fall off, thus leaving the active sites on the surface of the filter media exposed and meaning the removal activity was recovered finally. Specifically, the removal of $\mathrm{NH}_{4}{ }^{+}$and $\mathrm{Mn}^{2+}$ is closely related to the -OH groups on the surface of the Fe-Mn co-oxides [26,40]. The possible mechanisms by which the alkalinity affected the activity of the Fe-Mn co-oxides is summarized in Figure 11. The active sites (-OH groups) 
on the surface of the inactivated Fe-Mn co-oxides (Figure 11a) were occupied by the remaining $\mathrm{Al}$. After increasing alkalinity, $\mathrm{Mn}-\mathrm{O}-\mathrm{Al}$ combined with $\mathrm{HCO}_{3}{ }^{-}$to form $\mathrm{Al}_{2}\left(\mathrm{CO}_{3}\right)_{3}$, which caused $\mathrm{Al}$ to fall off and the active sites to be exposed (Figure 11b). Thus, the $\mathrm{NH}_{4}{ }^{+}$and $\mathrm{Mn}^{2+}$ removal activities were recovered and remained superior even after ceasing to add $\mathrm{HCO}_{3}{ }^{-}$.

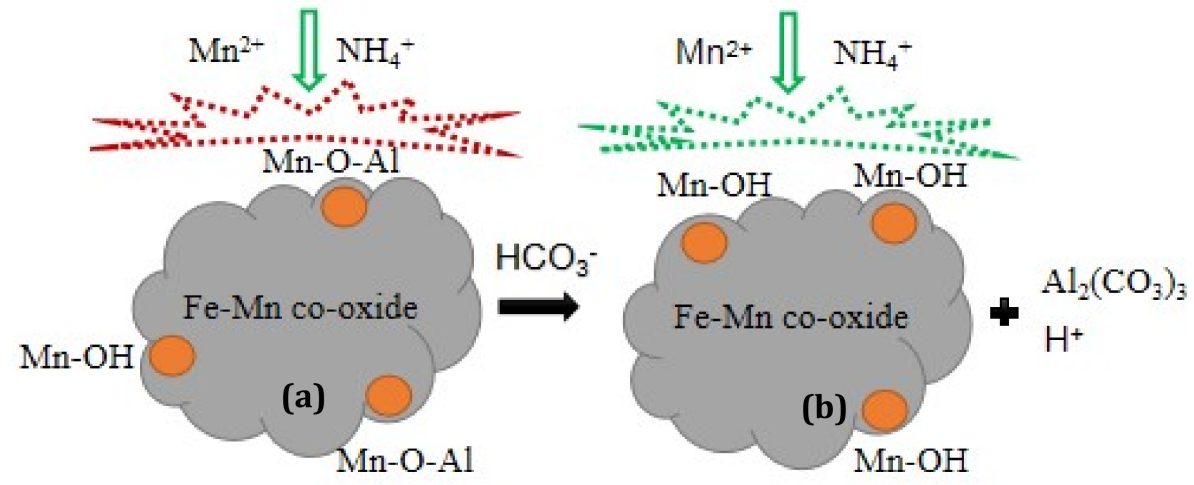

Figure 11. Mechanism of the influence of alkalinity on the $\mathrm{NH}_{4}{ }^{+}$and $\mathrm{Mn}^{2+}$ removal activity of Fe-Mn co-oxide, (a) inactivated, and (b) active Fe-Mn co-oxide filter media.

\section{Conclusions}

In this paper, the effects of $\mathrm{HCO}_{3}{ }^{-}$alkalinity on the catalytic properties of $\mathrm{Fe}-\mathrm{Mn}$ co-oxide for $\mathrm{NH}_{4}{ }^{+}$and $\mathrm{Mn}^{2+}$ removal from surface water were studied. The results suggest that the increase in alkalinity had a positive effect on the $\mathrm{NH}_{4}{ }^{+}$and $\mathrm{Mn}^{2+}$ removal activities of the inactivated filter media. In addition, after a period of operation under high alkaline conditions, the high activity of the filter column remained even if $\mathrm{NaHCO}_{3}$ was no longer added. Analysis of the filter media characterization indicated that the increase in $\mathrm{NH}_{4}{ }^{+}$and $\mathrm{Mn}^{2+}$ removal activities with the increase of alkalinity might have arisen from the structural change, which was caused by the actions of $\mathrm{Al}$ and $\mathrm{HCO}_{3}{ }^{-}$. These resulted in the re-exposure of the active sites occupied by residual $\mathrm{Al}$ and the recovery of the removal activity.

Author Contributions: Conceptualization, T.H.; Data Curation, Y.C.; Formal Analysis, Y.C.; Investigation, S.Z., F.H., M.G., and X.N.; Methodology, Y.C. and T.H.; Writing - Original Draft, Y.C. and S.Z. All authors approved the final version of the manuscript.

Funding: This research was financially supported by the National Natural Science Foundation of China (No. 51778521), the National Key Research Program (No. 2016YFC0400706), the China Postdoctoral Science Foundation (No. 2018M643808XB), and the Key Laboratory of Education Department of Shaanxi province (No. 19JS039).

Acknowledgments: We would like to thank Editage (www.editage.cn) for English language proofreading.

Conflicts of Interest: The authors declare no conflict of interest.

\section{References}

1. Tekerlekopoulou, A.G.; Papazafiris, P.G.D.; Vayenas, D.V. A full-scale trickling filter for the simultaneous removal of ammonium, iron and manganese from potable water. J. Chem. Technol. Biotechnol. 2010, 85, 1023-1026. [CrossRef]

2. Hasan, H.A.; Abdullah, S.R.S.; Kamarudin, S.K.; Kofli, N.T.; Anuar, N. Simultaneous $\mathrm{NH}_{4}{ }^{+}-\mathrm{N}$ and $\mathrm{Mn}^{2+}$ removal from drinking water using a biological aerated filter system: Effects of different aeration rates. Sep. Purif. Technol. 2013, 118, 547-556. [CrossRef]

3. Vries, D.; Bertelkamp, C.; Kegel, F.S.; Hofs, B.; Dusseldorp, J.; Bruins, J.H.; Vet, W.; Akkera, B. Iron and manganese removal: Recent advances in modelling treatment efficiency by rapid sand filtration. Water Res. 2016, 109, 35-45. [CrossRef] [PubMed]

4. Tekerlekopoulou, A.G.; Pavlou, S.; Vayenas, D.V. Removal of ammonium, iron and manganese from potable water in biofiltration units: A review. J. Chem. Technol. Biotechnol. 2013, 88, 751-773. [CrossRef] 
5. Abu Hasan, H.; Sheikh Abdullah, S.R.; Kamarudin, S.K.; Tan Kofli, N.; Anuar, N. Kinetic evaluation of simultaneous COD, ammonia and manganese removal from drinking water using a biological aerated filter system. Sep. Purif. Technol. 2014, 130, 56-64. [CrossRef]

6. Markesbery, W.R.; Ehmann, W.D.; Alauddin, M.; Hossain, T.I.M. Brain trace element concentrations in aging. Neurobiol. Aging. 1984, 5, 19-28. [CrossRef]

7. Vayenas, D.V.; Pavlou, S.; Lyberatos, G. Development of a dynamic model describing nitrification and nitratification in trickling filters. Water Res. 1997, 31, 1135-1147. [CrossRef]

8. Cai, Y.; Li, D.; Liang, Y.; Luo, Y.; Zeng, H.; Zhang, J. Effective start-up biofiltration method for Fe, Mn, and ammonia removal and bacterial community analysis. Bioresour. Technol. 2015, 176, 149-155. [CrossRef]

9. Vocciante, M.; D’Auris, A.D.; Finocchi, A.; Tagliabue, M.; Bellettato, M.; Ferrucci, A.; Reverberi, A.P.; Ferro, S. Adsorption of ammonium on clinoptilolite in presence of competing cations: Investigation on groundwater remediation. J. Clean. Prod. 2018, 198, 480-487. [CrossRef]

10. Zhang, H.; Feng, J.; Chen, S.; Zhao, Z.; Li, B.; Wang, Y.; Jia, J.; Li, S.; Wang, Y.; Yan, M.; et al. Geographical patterns of nirs gene abundance and nirs-type denitrifying bacterial community associated with activated sludge from different wastewater treatment plants. Microb. Ecol. 2019, 77, 304-316. [CrossRef]

11. Gerke, T.L.; Little, B.J.; Maynard, J.B. Manganese deposition in drinking water distribution systems. Sci. Total Environ. 2016, 541, 184-193. [CrossRef] [PubMed]

12. Tobiason, J.E.; Bazilio, A.; Goodwill, J.; Mai, X.; Nguyen, C. Manganese removal from drinking water sources. Curr. Pollut Rep. 2016, 2, 168-177. [CrossRef]

13. Wasserman, G.A.; Liu, X.; Parvez, F.; Ahsan, H.; Levy, D.; Factor-Litvak, P.; Kline, J.; van Geen, A.; Slavkovich, V.; Lolacono, N.J.; et al. Water manganese exposure and children's intellectual function in Araihazar, Bangladesh. Environ. Health Perspect. 2006, 114, 124-129. [CrossRef] [PubMed]

14. Bouchard, M.F.; Sauvé, S.; Barbeau, B.; Legrand, M.; Brodeur, M.-E.; Bouffard, T.; Limoges, E.; Bellinger, D.C.; Mergler, D. Intellectual impairment in school-age children exposed to manganese from drinking water. Environ. Health Perspect. 2010, 119, 138-143. [CrossRef] [PubMed]

15. Martinez-Finley, E.J.; Gavin, C.E.; Aschner, M.; Gunter, T.E. Manganese neurotoxicity and the role of reactive oxygen species. Free Radical Bio. Med. 2013, 62, 65-75. [CrossRef] [PubMed]

16. Ates, A. Role of modification of natural zeolite in removal of manganese from aqueous solutions. Powder Technol. 2014, 264, 86-95. [CrossRef]

17. Frisbie, S.H.; Mitchell, E.J.; Dustin, H.; Maynard, D.M.; Sarkar, B. World health organization discontinues its drinking-water guideline for manganese. Environ. Health Persp. 2012, 120, 775-778. [CrossRef]

18. Wang, X.; Lü, S.; Gao, C.; Xu, X.; Zhang, X.; Bai, X.; Liu, M.; Wu, L. Highly efficient adsorption of ammonium onto palygorskite nanocomposite and evaluation of its recovery as a multifunctional slow-release fertilizer. Chem. Eng. J. 2014, 252, 404-414. [CrossRef]

19. Khuntia, S.; Majumder, S.K.; Ghosh, P. Removal of ammonia from water by ozone microbubbles. Ind. Eng. Chem. Res. 2013, 52, 318-326. [CrossRef]

20. Zhu, X.; Castleberry, S.R.; Nanny, M.A.; Butler, E.C. Effects of $\mathrm{pH}$ and catalyst concentration on photocatalytic oxidation of aqueous ammonia and nitrite in titanium dioxide suspensions. Environ. Sci. Technol. 2005, 39, 3784-3791. [CrossRef]

21. Kim, K.W.; Kim, Y.J.; Kim, I.T.; Park, G.I.; Lee, E.H. Electrochemical conversion characteristics of ammonia to nitrogen. Water Res. 2006, 40, 1431-1441. [CrossRef] [PubMed]

22. Cheng, Q. Competitive mechanism of ammonia, iron and manganese for dissolved oxygen using pilot-scale biofilter at different dissolved oxygen concentrations. Water Sci. Tech.-W. Sup. 2016, 16, 766-774. [CrossRef]

23. Li, K.; Wen, G.; Li, S.; Chang, H.; Shao, S.; Huang, T.; Li, G.; Liang, H. Effect of pre-oxidation on low pressure membrane (LPM) for water and wastewater treatment: A review. Chemosphere 2019, 231, 287-300. [CrossRef] [PubMed]

24. Hoyland, V.W.; Knocke, W.R.; Falkinham, J.O.; Pruden, A.; Singh, G. Effect of drinking water treatment process parameters on biological removal of manganese from surface water. Water Res. 2014, 66, 31-39. [CrossRef] [PubMed]

25. Su, J.; Bai, Y.; Huang, T.; Li, W.; Gao, C.; Wen, Q. Multifunctional modified polyvinyl alcohol: A powerful biomaterial for enhancing bioreactor performance in nitrate, $\mathrm{Mn}(\mathrm{II})$ and Cd(II) removal. Water Res. 2020, 168, 115-152. [CrossRef] 
26. Tekerlekopoulou, A.G.; Vasiliadou, I.A.; Vayenas, D.V. Biological manganese removal from potable water using trickling filters. Biochem. Engineering, J. 2008, 38, 292-301. [CrossRef]

27. Guo, Y.; Huang, T.; Wen, G.; Cao, X. The simultaneous removal of ammonium and manganese from groundwater by iron-manganese co-oxide filter film: The role of chemical catalytic oxidation for ammonium removal. Chem. Eng. J. 2017, 308, 322-329. [CrossRef]

28. Cheng, Y.; Huang, T.; Sun, Y.; Shi, X. Catalytic oxidation removal of ammonium from groundwater by manganese oxides filter: Performance and mechanisms. Chem. Eng. J. 2017, 322, 82-89. [CrossRef]

29. Zhang, R.; Huang, T.; Wen, G.; Chen, Y.; Cao, X.; Zhang, B.; Wang, B. Phosphate dosing to sustain the ammonium removal activity of an iron-manganese co-oxide filter film at pilot scale: Effects on chemical catalytic oxidation. Chem. Eng. J. 2018, 334, 1186-1194. [CrossRef]

30. Cheng, Y.; Zhang, S.; Huang, T.; Cheng, L.; Yao, X. Effects of coagulants on the catalytic properties of iron-manganese co-oxide filter films for ammonium and manganese removal from surface water. J. Clean. Prod. 2019, 242, 118494. [CrossRef]

31. Cheng, Y.; Li, Y.; Huang, T.; Sun, Y.; Shi, X.; Shao, Y. A comparison study of the start-up of a MnOx filter for catalytic oxidative removal of ammonium from groundwater and surface water. J. Environ. Sci. 2018, 65, 327-334. [CrossRef] [PubMed]

32. Cheng, Y.; Huang, T.; Liu, C.; Zhang, S. Effects of dissolved oxygen on the start-up of manganese oxides filter for catalytic oxidative removal of manganese from groundwater. Chem. Eng. J. 2019, 371, 88-95. [CrossRef]

33. Li, C.; Wang, S.; Du, X.; Cheng, X.; Fu, M.; Hou, N.; Li, D. Immobilization of iron- and manganese-oxidizing bacteria with a biofilm-forming bacterium for the effective removal of iron and manganese from groundwater. Bioresour. Technol. 2016, 220, 76-84. [CrossRef] [PubMed]

34. Single Euro Payments Area (SEPA). Analytical Methods of Water and Wastewater, 4th ed.; China Environmental Science Press: Beijing, China, 2002.

35. Yang, H.; Li, D.; Zeng, H.; Zhang, J. Impact of Mn and ammonia on nitrogen conversion in biofilter coupling nitrification and ANAMMOX that simultaneously removes Fe, Mn and ammonia. Sci. Total Environ. 2019, 648, 955-961. [CrossRef]

36. Katsoyiannis, I.A.; Zouboulis, A.I. Biological treatment of $\mathrm{Mn}(\mathrm{II})$ and Fe(II) containing groundwater: Kinetic considerations and product characterization. Water Res. 2004, 38, 1922-1932. [CrossRef]

37. Zhang, R.; Huang, T.; Wen, G.; Chen, Y.; Cao, X.; Zhang, B. Using iron-manganese Co-oxide filter film to remove ammonium from surface water. Int. J. Environ. Res. Public Health 2017, 14, 1-12. [CrossRef]

38. Funes, A.; De, V.J.; Cruz-Pizarro, L.; De, V.I. The influence of $\mathrm{pH}$ on manganese removal by magnetic microparticles in solution. Water Res. 2014, 53, 110-122. [CrossRef]

39. Cheng, Y.; Huang, T.; Cheng, L.J.; Sun, Y.; Zhu, L.S.; Li, Y. Structural characteristic and ammonium and manganese catalytic activity of two types of filter media in groundwater treatment. J. Environ. Sci. 2018, 72, 91-99. [CrossRef]

40. Eslami, H.; Ehrampoush, M.H.; Esmaeili, A.; Salmani, M.H.; Ebrahimi, A.A.; Ghaneian, M.T.; Falahzadeh, H.; Fard, R.F. Enhanced coagulation process by Fe-Mn bimetal nano-oxides in combination with inorganic polymer coagulants for improving As (V) removal from contaminated water. J. Clean. Prod. 2018, 208, 384-392. [CrossRef]

41. Seredych, M.; Bandosz, T.J. Manganese oxide and graphite oxide/ $\mathrm{MnO}_{2}$ composites as reactive adsorbents of ammonia at ambient conditions. Micropor. Mesopor. Mat. 2012, 150, 55-63. [CrossRef]

42. Joshi, T.P.; Zhang, G.; Cheng, H.; Liu, R.; Liu, H.; Qu, J. Transformation of, para, arsanilic acid by manganese oxide: Adsorption, oxidation, and influencing factors. Water Res. 2017, 116, 126-134. [CrossRef]

43. Vázquez-Olmos, A.; Redón, R.; Rodríguez-Gattorno, G.; Mata-Zamora, M.E.; Morales-Leal, F.; Fernández-Osorio, A.L.; Sanigera, J.M. One-step synthesis of $\mathrm{Mn}_{3} \mathrm{O}_{4}$ nanoparticles: Structural and magnetic study. J. Colloid Interf. Sci. 2005, 291, 175-180.

(C) 2020 by the authors. Licensee MDPI, Basel, Switzerland. This article is an open access article distributed under the terms and conditions of the Creative Commons Attribution (CC BY) license (http://creativecommons.org/licenses/by/4.0/). 